\title{
海底面を水平方向に伝播する地震波に対する 浮遊式海洋人工島の海震応答 \\ SEAQUAKE RESPONSE OF FLOATING ISLANDS FOR HORIZONTALLY TRAVELING SEISMIC WAVE ON SEA BED
}

\author{
濱 本 卓 司*, 三角 猛二郎** \\ Takuji HAMAMOTO and Takejiro MISUMI
}

The stochastic response of a large floating island for seaquakes induced by horizontally traveling seismic wave on sea bed is formulated, taking account of structural flexibility and fluidstructure interaction. The floating island is idealized as an elastic circular plate with or without tension-legs. Hydrodynamic pressure acting on the floating island is obtained in closed form on the basis of a linear potential flow theory. The response quantities are evaluated by a wet-mode superposition approach and stationary random vibration theory. Numerical examples are presented to discuss the difference in the response behaviors of the floating island against horizontally traveling and vertically incident waves.
Keywords : large floating island, fluid-structure interaction, seaquake, horizontally traveling seismic wave, potential flow theory, elastic circular plate 浮遊式海洋人工島, 流体一構造物相互作用, 海震, 水平方向進行波, ポテン シャル流れ理論, 弾性円板

\section{1. 序}

海洋性地震が頻発する我国近海の海域に浮遊式海洋構 造物を建設する場合, 波浪や風とともに地震が重要な荷 重要因となる。海水はせん断波を伝播しない媒体である ため, アンカーのない浮遊式海洋構造物は海底面での水 平地動に対しては免震構造物と見なすことができる。し かし, 海底面の動きが上下動になると海水中を高振動数 の疎密波が伝播する海震現象が生じ, もはや免震構造物 とは呼べなくなる。また，アンカーを有する場合は，水 平地動・上下地動にかかわらず熬留索を直接地震波が伝 播し応答を増幅する。

海震による船舶の被害は数多く報告されており, 浮遊 式海洋構造物にとっても重要な荷重要因となることが指 摘されている13,2)。馬場引は自由浮体としての浮遊式海洋 構造物の海震応答に関する理論的および実験的研究を 行った。川西・池田・加藤(4) 栖・加藤・小林5)(それ ぞれオフセットがない場合とある場合のテンションレ
グ・プラットフォームを対象に，上下地動により生じる 繫留索の変動張力に対する応答挙動を検討した。Liou・ Penzien・Yeung $\left.{ }^{6}\right)$ は，海震現象とテンションレグ繫留に よる変動張力をともに考慮して円筒浮体の上下地動に対 する応答挙動を検討した。以上の研究は, 海底油田掘削 プラットフォームあるいは原子カプラント海上立地を対 象とし，浮体は剛体として扱われている。これに対し， 濱本・田中学は海上都市や海上空港等の大規模浮遊式海 洋人工島を対象構造物とし，構造物自体の変形を考慮し た構造物 流体相互作用問題を定式化し海震時の応答挙 動を検討した。この際，海底面は剛体的に上下動するも のと考之，海水中を鉛直方向に伝播する疎密波が同位相 で浮体底面に作用する場合の応答を扱った。これは, P 波 が海底地盤を鉛直下方から伝播してくる場合に対応して いる。しかし，実際には P 波あるいは SV 波が海底面に 斜め入射する場合，あるいはレーリ一波が入射する場合 にも海底面の上下動は励起され，位相差をもって水平方
* 武蔵工業大学工学部建築学科 教授 $\cdot$ 工博

** 大成建設構造設計部 工修
Professor, Faculty of Engineering, Dept. of Architecture, Musashi Institute of Technology, Dr. Eng.

Structural Engineering Dept., Taisei Corporation, M. Eng. 
向に伝播する進行波となる8),9)。のことは，P 波のみで なく $\mathrm{S}$ 波あるいは表面波もまた海震のエネルギーに変 換されることを意味している。

水平方向に伝播する地震波に対する応答解析は，すで に冷却塔 ${ }^{10)}$, 原子力発電所 ${ }^{11)}$, 長大橋 ${ }^{12)}$, 埋設パイプライ ン13)等の長大構造物に対して行われている。この位相差 入力により構造物に局所的な変形や応力集中が生じるこ とが指摘されており，大規模構造物の酎震設計において 留意すべき事項の一つとなっている。大規模浮遊式人工 島の場合もまた，直接地盤とは接していないものの，海 水を介してこの位相差入力の影響を受ける。海底面が同 位相で上下動する場合，円形人工島には軸対称応答のみ が励起される。しかし, 海底面を水平方向に進行波が伝 播する場合には，空間的に位相差をもった疎密波が作用 することになる。したがって, 波浪応答 ${ }^{14)}$ と同様に非軸詨 称応答となり, 励起されるモ一ドの数が増加して人工島 の応答の空間分布ははるかに複雑になる。本研究では, 海底面での上下動が位相差を有する場合の浮遊式海洋人 工島の海震応答を定式化し, 数值結果に基づき海底面が 同位相で上下動した場合との違いを明らかにする。

\section{2. 解析モデルと仮定}

海底面を水平方向に伝播する地震波により生じる海底 地盤の上下動に対して応答する浮遊式海洋円形人工島を Fig. 1 に示す。人工島の形状寸法および設置状態は以下 のパラメータにより定義される。 $a$ : 人工島の半径, $h$ : 人工島の厚さ, $d$ : 静稳な状態における海面から海底ま での深さ (設置水深), $\bar{d}$ : 人工島下面から海底までの樑 さ (したがって人工島の吃水は $d-\bar{d}), U_{g}$ : 地震による 海底面の上下変位, $C_{a}$ : 海底面を水平方向に伝播する地 震波の見かけ速度。座標系として, 円形人工島の中心を 海底面に投影した点を原点とする円筒座標系 $(r, \theta, z)$ を用いる。槃留方法は，アンカーのない自由浮体方式と テンションレグによるアンカー方式とし，アンカー方式 では人工島の周辺に沿ってテンションレグをリング状に 配置した場合（リング状アンカー）と人工島下面に一様 に分布させた場合（分布アンカー）の二通りを考之る。 Fig. 2 に考慮する 3 タイプの繫留方式を示す。

位相差を有する海底地盤の上下動により地震波は海水 中を踈密波として伝播し，人工島下面に動水圧が発生す る。媻留する場合は, 動水圧に加之て鉛直繫留索の変動 張力が作用し，人工島は鉛直 (ヒーブ)および回転 (ピッ チ）の剛体運動と弾性変形との連成で応答する。海震時 における人工島一海水一熬留索連成系の応答挙動を定式 化するために，本研究では以下の仮定を用いる。

1) 円形人工島は線形弾性であり，その運動は線形振動 の範囲内にある。

2 ）海水は渦なし・非粘性・非圧縮性である。

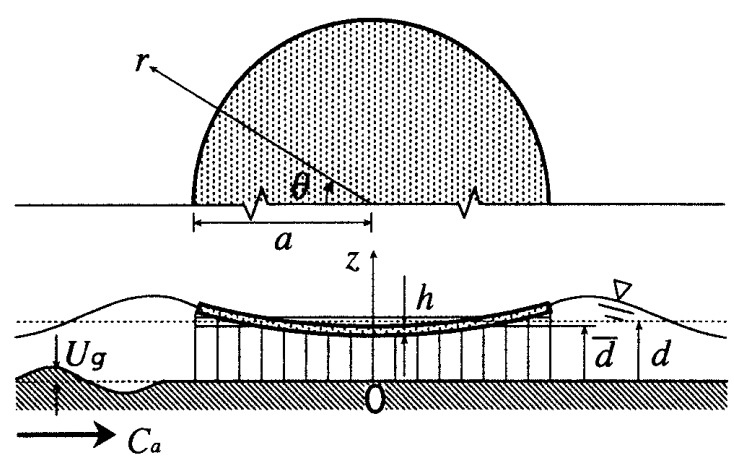

Fig. 1 Geometric parameters of floating island under hori. zontally traveling seismic wave

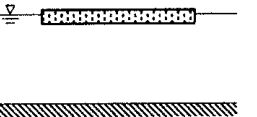

(a) Without anchor

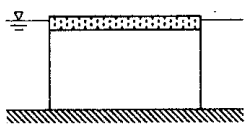

(b) Ring anchor

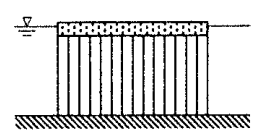

(c) Distributed anchor
Fig. 2 Three mooring states of flexible circular floating island

3）關留索には常時引張力が作用しており, その復元力 特性は線形である。

4) 椠留索の質量効果は無視できる。

5 ）海底面の上下動は，一定の見かけ速度で水平方向に 伝播する不規則な平面波により生じる。

6) 入力地震動は主要動の定常部のみを考之, その上下 動加速度は平均値 0 の定常エルゴード過程である。

7）海底面は水平で海水領域は無限に広がっている。

なお，柾密波の伝播は圧縮性流体における現象である が, 圧縮性流体と非圧縮性流体における差は一次元波動 場の共振振動数近傍を除きほとんどなく，本研究のよう な二次元波動場ではこの共振振動数も現れないため2） において非圧縮性を仮定した[文献?)の補遺 3 参照]。

\section{3. 動水圧と繫留力}

海底面を水平方向に伝播する地震波を考えると，海底 面の上下動は位相差を有することになる。このため, 海 震現象により人工島下面に作用する動水圧は空間的に複 雑に分布し，人工島の運動も海底面が位相差なしで上下 剛体運動する場合の軸対称運動とは異なり, 風波に対す る応答と同㥞に以下のような鉛直（ヒーブ）および回転 (ピッチ)の剛体運動と非軸対称モードを含む面外弾性変 形との連成で応答する。

$$
\zeta=\xi+\omega r \cos \theta+w
$$

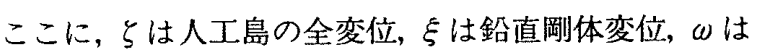
回転剛体運動の回転角, $w$ は面外弾性変形である。人工 島の全変位 のウェットモード形の重ね合わせにより，また媻留状態 では人工島～海水～熬留索連成系のウェットモード形の 


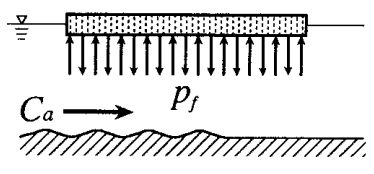
due to ground motion (a) Hydrodynamic pressure

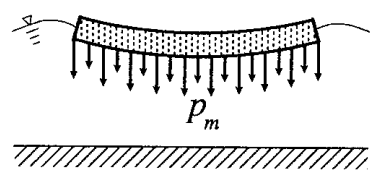

(b) Hydrodynamic pressure due to island motion
Fig. 3 Two components of hydrodynamic pressure when subjected to seaquakes

重ね合わせにより以下のように表せる。

$$
\zeta=\sum_{n=0}^{\infty} \sum_{m=1}^{\infty} \zeta_{n m}(r) \cos n \theta q_{n m}(t)
$$

ここに, 下添字 $n$ は円周方向フーリ工波数, $m$ は半径 方向モ一ド次数, $\zeta_{n m}(r)$ は流体連成自由振動解析 ${ }^{15), 16) て ゙ ~}$ 求めた人工島の境界条件を満足する $\theta=0$ における $\mathrm{nm}$ 次の半径方向モード形, $q_{n m}(t)$ は $n m$ 次一般化座標, $t$ は 時間である。

海震による入射波は, 人工島の存在により反射・散乱 され，さらに人工島の運動により放射状に広がる表面波 が発生する。このような波動現象に伴い, 人工島下面に 作用する波圧分布は変化する。海震を受けて運動する人 工島に作用する動水圧 $p$ は, Fig. 3 に示すように, (i)人工 島を自由浮体時あるいは繫留時の釣合い位置に固定した 状態において海震の作用により生じる動水圧成分 $p_{f}$ と (ii)海震の作用のない静穞な状態において人工島の運動に より発生する動水圧成分 $p_{m}$ との和となる。

$$
p=p_{f}+p_{m}
$$

人工島の平面形状が円形の場合, 式(3)の右辺の各動水 圧成分は線形ポテンシャル理論に基づき解析解として求 めることができる。

\section{$3-1$ 動水圧成分 $p_{f}$ の誘導}

位相差を有する海底面での上下動により釣合い位置に 固定された人工島の下面に生じる動水圧成分 $p_{f}$ は, Fig. 4 に示すように, さらに以下の動水圧成分の和として表 わせる。すなわち，(i)人工島の存在しない free-field にお いて，釣合い位置にある人工島の下面レベルに海震の作 用により生じる入射波の動水圧成分 $p_{i}$ と(ii)人工島の存 在により生じる入射波の反射・散乱に伴う動水圧成分 $p_{s}$ である。

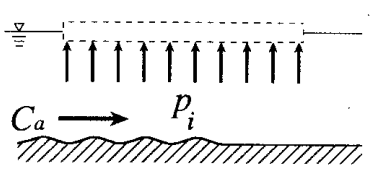

(a) Hydrodynamic pressure due to incident wave

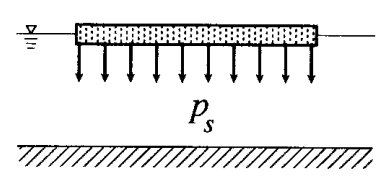

(b) Hydrodynamic pressure due to scattered wave

Fig. 4 Two components of hydrodynamic pressure due to ground motion

$$
p_{f}=p_{i}+p_{s}
$$

人工島下面に作用する入射波の動水圧成分 $p_{i}$ は, 速度 ポテンシャル $\phi_{i}$ に関する以下の境界值問題を解くこと により求まる。

$$
\begin{aligned}
\nabla^{2} \phi_{i} & =\frac{\partial^{2} \phi_{i}}{\partial r^{2}}+\frac{1}{r} \frac{\partial \phi_{i}}{\partial r}+\frac{1}{r^{2}} \frac{\partial^{2} \phi_{i}}{\partial \theta^{2}}+\frac{\partial^{2} \phi_{i}}{\partial z^{2}}=0 \\
& : 0 \leq z \leq d \cdots \cdots \\
\frac{\partial \phi_{i}}{\partial z}+\frac{1}{g} \frac{\partial^{2} \phi_{i}}{\partial t^{2}}=0 & : z=d \cdots \cdots \cdots \\
\frac{\partial \phi_{i}}{\partial z}=\dot{U}_{g} & : z=0 \cdots \cdots \cdots
\end{aligned}
$$

ここに, $g$ は重力加速度, ・= $\partial / \partial t$ である。式 (5a)は渦 なし・非粘性・非圧縮性の流体場を支配するL Laplace 方 程式, 式 (5b) は海面における自由表面境界条件, 式 $(5 \mathrm{c})$ は海底における海水と地盤との運動の連続条件である。

海底を不規則な進行波が見かけ速度 $C_{a}$ で水平方向 $(\theta$ $=0)$ に伝播するとき, 海底面での上下動加速度は各成分 波の重ね合わせとして次式で表される。

$$
\begin{aligned}
\ddot{U}_{g}(r, \theta, t)= & \sum_{l=1}^{\infty} \sqrt{2 S_{\ddot{U}_{\theta} \ddot{U}_{s}}\left(\sigma_{l}\right) \Delta \sigma} \\
& \cdot \exp \left[i\left(\sigma_{l} t-k_{l} r \cos \theta+\varphi_{l}\right)\right]
\end{aligned}
$$

ここに， $S_{\dot{U}_{s} \dot{U}_{g}}\left(\sigma_{l}\right)$ は海底面での上下動加速度のパワー スペクトル密度関数， $\sigma_{l}, k_{l}$, および $\varphi_{l}$ はそれぞれ $l$ 番 目の成分波の円振動数, 波数, および位相, $\Delta \sigma=\left(\sigma_{l+1}\right.$ - $\left.\sigma_{l-1}\right) / 2$ である。なお, 円振動数と波数の間には以下の 関係がある。

$$
k_{l}=\frac{\sigma_{l}}{C_{a}}
$$

式(6)において以下の Fourier-Bessel 展開を利用する。

$$
\exp \left[-i k_{l} r \cos \theta\right]=\sum_{n=0}^{\infty} \gamma_{n}(-i)^{n} J_{n}\left(k_{\iota} r\right) \cos n \theta
$$

ここに， $\gamma_{0}=1, \gamma_{n}=2(n \geq 1)$ である。式(8)を式(6)に 代大すると次式を得る。

$$
\begin{aligned}
\ddot{U}_{g}(r, \theta, t)= & \sum_{l=1}^{\infty} \sum_{n=0}^{\infty} \sqrt{2 S_{\ddot{U}_{s}} \ddot{U}_{s}\left(\sigma_{l}\right) \Delta \sigma} \gamma_{n}(-i)^{n} J_{n}\left(k_{l} r\right) \\
& \cdot \cos n \theta \exp \left(i \sigma_{l} t+\varphi_{l}\right) \quad \ldots \ldots \ldots \ldots \ldots \ldots
\end{aligned}
$$

一方, 反射・散乱波の動水圧成分 $p_{s}$ は, 海面での境界 条件が $r=a$ の円筒状の境界の内外で異なるため, Fig. 5 に示すように, 海水領域を円形人工島直下の内部領域 $(r$ $<a)$ とそれ以外の外部領域 $(r>a)$ に分割し，それぞれ の領域で境界值問題をたてることにより求められる。内 部領域での反射波の速度ポテンシャル $\phi_{s}^{(i)}$ は以下の境 界值問題を満足する。

$$
\begin{array}{ll}
\nabla^{2} \phi_{s}^{(i)}=0 & : 0 \leq z \leq \bar{d}, r<a \cdots \cdots(10 \mathrm{a}) \\
\frac{\partial \phi_{s}^{(i)}}{\partial z}=-\frac{\partial \phi_{i}}{\partial z} & : z=\bar{d}, r<a \cdots \cdots \cdots(10 \mathrm{~b})
\end{array}
$$




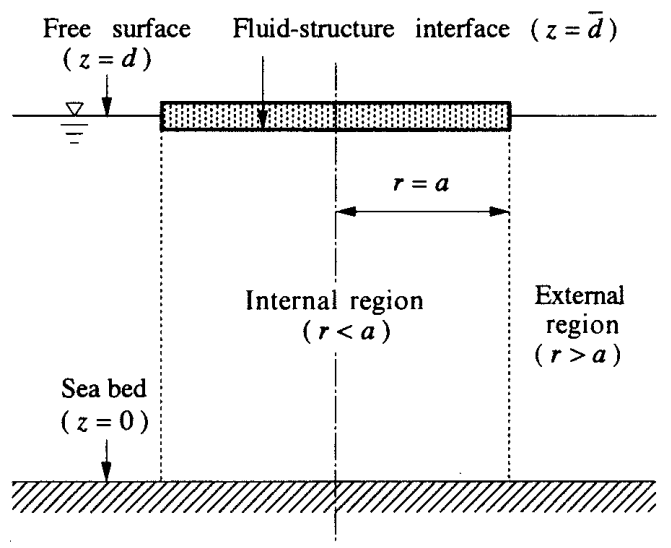

Fig. 5 Fluid domain divided into two regions

$$
\frac{\partial \phi_{s}^{(i)}}{\partial z}=0
$$$$
: z=0, r<a
$$

式 (10b) は人工島下面での固体境界条件であり，入射 波を完全反射することを示している。外部領域での反射 波の速度ポテンシャル $\phi_{s}^{(e)}$ は以下の境界值問題を満足 する。

$$
\begin{array}{ll}
\nabla^{2} \phi_{s}^{(e)}=0 & : 0 \leq z \leq d, r>a \\
\frac{\partial \phi_{s}^{(e)}}{\partial z}+\frac{1}{g} \frac{\partial^{2} \phi_{s}^{(e)}}{\partial t^{2}}=0 & : z=d, r>a \\
\frac{\partial \phi_{s}^{(e)}}{\partial z}=0 & : z=0, r>a \cdots \\
\lim _{r \rightarrow \infty} r^{\frac{1}{2}}\left(\frac{\partial \phi_{s}^{(e)}}{\partial r}+i k \phi_{s}^{(e)}\right)=0 \quad: r \rightarrow \infty \cdots \cdots
\end{array}
$$

式(11d)は無限遠点における放射条件を表している。 式(6)を式 $(5 c)$ に代入し，式 $(5 a \sim c)$ を満足する入射波 の速度ポテンシャル $\phi_{i}$ を求める。以下では簡略化のた めに式(6)に示した不規則波の一成分波について考之るこ とにし， $l$ 番目の成分であることを示す添字 $l$ を省略す る。円振動数 $\sigma$ の調和成分波が見かけ速度 $C_{a}$ で水平方 向 $(\theta=0)$ に伝播する場合の解は変数分離法により以下 のように求まる。

$$
\begin{aligned}
& \phi_{i}(r, \theta, z, t)= \\
& \quad \frac{V_{o}}{k} \frac{-k g \cosh k(d-z)+\sigma^{2} \sinh k(d-z)}{k g \sinh k d-\sigma^{2} \cosh k d} \\
& \quad \cdot \exp [i(\sigma t-k r \cos \theta)] \ldots \ldots \ldots \ldots \ldots \ldots \ldots \ldots \ldots \ldots \ldots \ldots \ldots \ldots \ldots \ldots
\end{aligned}
$$

ここに, $V_{0}=A_{0} / i \sigma, A_{0}=\sqrt{2 S_{U_{o} U_{o}}(\sigma) \Delta \sigma}$ である。式(8) を式(12)に代入すると次式を得る。

$$
\begin{aligned}
\phi_{i}(r, \theta, z, t)= & \sum_{n=0}^{\infty} \frac{V_{0} \gamma_{n}(-i)^{n}}{k} \\
& \cdot \frac{-k g \cosh k(d-z)+\sigma^{2} \sinh k(d-z)}{k g \sinh k d-\sigma^{2} \cosh k d} \\
& \cdot J_{n}(k r) \cos n \theta \exp (i \sigma t) \ldots \ldots \ldots \ldots \ldots \ldots(1)
\end{aligned}
$$

式 $(10 \mathrm{a} \sim \mathrm{c})$ を満足する内部領域での反射波の速度ポ
テンシャル $\phi_{s}^{(i)}$ は以下のように与えられる。

$$
\phi_{s}^{(i)}=\phi_{s h}^{(i)}+\phi_{s p}^{(i)}
$$

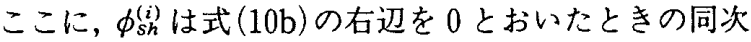
解, $\phi_{S p}^{(i)}$ は式 $(10 \mathrm{a} \sim \mathrm{c})$ を満足する特解であり，それぞれ以 下のように求まる。

$$
\begin{aligned}
\phi_{s h}^{(i)}= & \sum_{n=0}^{\infty}\left\{D_{n 0}\left(\frac{r}{a}\right)^{n}+\sum_{s=1}^{\infty} D_{n s} \frac{I_{n}\left(l_{s} r\right)}{I_{n}\left(l_{s} a\right)} \cos l_{s} z\right\} \\
& \cdot \cos n \theta \exp (i \sigma t) \quad \ldots \ldots \ldots \ldots \ldots \ldots \ldots \ldots \ldots \ldots \ldots \ldots \ldots \ldots \ldots \ldots \ldots \ldots \ldots \\
\phi_{s p}^{(i)}= & \sum_{n=0}^{\infty} \sum_{s=1}^{\infty} \gamma_{n}(-i)^{n} \frac{2 V_{0}}{a \lambda_{n s}} \\
. & \frac{k g \sinh k(d-\bar{d})-\sigma^{2} \cosh k(d-\bar{d})}{k g \sinh k d-\sigma^{2} \cosh k d} \frac{J_{n}\left(\lambda_{n s}^{*} r\right)}{J_{n+1}^{2}\left(\lambda_{n s}\right)} \frac{\cosh \lambda_{n s}^{*} z}{\sinh \lambda_{n s}^{*} \bar{d}} \\
\cdot & \int_{0}^{a} J_{n}(k r) J_{n}\left(\lambda_{n s}^{*} r\right) r d r \cos n \theta \exp (i \sigma t) \cdots \ldots \ldots \ldots \ldots(15 \mathrm{~b}
\end{aligned}
$$

ここに, $I_{n}\left(l_{s} r\right)$ は $n$ 位の第 1 種変形ベッセル関数, $l_{s}$ $=s \pi / \bar{d}, D_{n 0}$ および $D_{n s}(n=1,2, \cdots)$ は末定係数, $\lambda_{n s}$ は $J_{n s}\left(\lambda_{n s}\right)=0$ を満足する正の $s$ 番目の根, $\lambda_{n s}^{*}=\lambda_{n s} / a$ であ る。式(11a d d )満足する外部領域での反射波の速度ポ テンシャル $\phi_{s}^{(e)}$ は次式で与えられる ${ }^{17)} 。$

$$
\begin{aligned}
\phi_{s}^{(e)}= & \sum_{n=0}^{\infty}\left\{B_{n 0} \frac{H_{n}^{(2)}(k r)}{H_{n}^{(2)}(k a)} \cosh k z+\sum_{j=1}^{\infty} C_{n j} \frac{K_{n}\left(k_{j} r\right)}{K_{n}\left(k_{j} a\right)}\right. \\
& \left.\cdot \cos k_{j} z\right\} \cos n \theta \exp (i \sigma t) \ldots \ldots \ldots \ldots \ldots \ldots \ldots
\end{aligned}
$$

ここに, $H_{n}^{(2)}(k r)$ は $n$ 位の第 2 種ハンケル関数, $K_{n}\left(k_{j} r\right)$ は $n$ 位の第 2 種変形ベッセル関数, 波数 $k$ およ び $k_{j}$ は超越方程式

$$
\sigma^{2}=k g \tanh k d=-k_{j} g \tan k_{j} d
$$

の根であり， $B_{n 0}$ および $C_{n j}(j=1,2, \cdots)$ は未定係数で ある。

两領域の速度ポテンシャルに関する境界值問題の解 は，上述したように未定係数を有する解析解として得ら

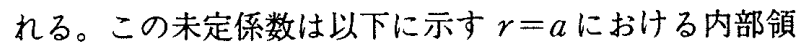
域と外部領域の連続条件により一意的に定めることがで きる。

$$
\begin{array}{ll}
\frac{\partial \phi_{s}^{(e)}}{\partial r}=\frac{\partial \phi_{s}^{(i)}}{\partial r} & : r=a, 0 \leq z \leq \bar{d} \\
\frac{\partial \phi_{s}^{(e)}}{\partial r}=0 & : r=a, \bar{d} \leq z \leq d \\
\phi_{s}^{(e)}=\phi_{s}^{(i)} & : r=a, 0 \leq z \leq \bar{d}
\end{array}
$$

式 (18a， b) は速度ポテンシャルの半径方向勾配の連続 条件（前者は海水の連続条件，後者は人工島側面におけ る固体境界条件)，式(19)は速度ポテンシャルの連続条件 (圧力の連続条件)を表している。

式(14)，(15a，b)，(16)を式(18a，b)に代入し， coshkzを 両辺に乗じ， $z$ に関して区間 $[0, d]$ で積分すると次式を 
得る。

$$
\begin{aligned}
& b_{n} B_{n 0}-d_{n} D_{n 0}-\sum_{s=1}^{\infty} \bar{I}_{n s} S_{n s} D_{n s}=E_{n} \sum_{s=1}^{\infty} \bar{J}_{n s} T_{n s} \widetilde{R}_{n s} \cdots(20) \\
& \text { ここに， } \\
& b_{n}=\frac{1}{4 k}(\sinh 2 k d+2 k d) \bar{H}_{n} \\
& d_{n}=\frac{n}{a k} \sinh k \bar{d} \\
& S_{n s}=\frac{k}{l_{s}^{2}+k^{2}} \cos s \pi \sinh k \bar{d} \\
& T_{n s}=\frac{1}{\lambda_{n s}^{* 2}-k^{2}}\left(\lambda_{n s}^{*} \cosh k \bar{d}-k \sinh k \bar{d} \operatorname{coth} \lambda_{n s}^{*} \bar{d}\right) \\
& \widetilde{R}_{n s}=\int_{0}^{a} J_{n}(k r) J_{n}\left(\lambda_{n s}^{*} r\right) r d r \\
& E_{n}=\gamma_{n}(-i)^{n} \frac{2 V_{0}}{a^{2}} \\
& \cdot \frac{k g \sinh k(d-\bar{d})-\sigma^{2} \cosh k(d-\bar{d})}{k g \sinh k d-\sigma^{2} \cosh k d} . \\
& \bar{H}_{n}=\frac{H_{n}^{(2)^{\prime}}(k a)}{H_{n}^{(2)}(k a)} k \\
& \bar{I}_{n s}=\frac{I_{n}^{\prime}\left(l_{s} a\right)}{I_{n}\left(l_{s} a\right)} l_{s} \\
& \bar{J}_{n s}=\frac{J_{n}^{\prime}\left(\lambda_{n s}\right)}{J_{n+1}^{2}\left(\lambda_{n s}\right)}
\end{aligned}
$$

式 $(21 \mathrm{~g}, \mathrm{~h}, \mathrm{i}) の^{\prime}$ はそれぞれ $\partial / \partial(k r), \partial / \partial\left(l_{s} r\right), \partial / \partial\left(\lambda_{n s}^{*}\right.$ $r)$ を表方している。なお，式(20)を導く際に以下の直交関 係を用いた。

$$
\int_{0}^{d} \cosh k z \cos k_{j} z d z=0
$$

式(14)，(15a，b)，(16)を式(18a，b)に代入し， $\cos k_{j} z$ を 両辺に乗じ， $z$ に関して区間 $[0, d]$ で積分すると次式を 得る。

$$
\begin{array}{r}
b_{n}^{(j)} C_{n j}-d_{n}^{(j)} D_{n 0}-\sum_{s=1}^{\infty} \bar{I}_{n s} S_{n s}^{(j)} D_{n s}=E_{n} \sum_{s=1}^{\infty} \bar{J}_{n s} T_{n s}^{(j)} \widetilde{R}_{n s} \\
(j=1,2, \cdots)
\end{array}
$$

ここに,

$$
\begin{aligned}
& b_{n}^{(j)}=\frac{1}{4 k_{j}}\left(\sin 2 k_{j} d+2 k_{j} d\right) \bar{K}_{n j} \\
& d_{n}^{(j)}=\frac{n}{a k_{j}} \sin k_{j} \bar{d} \\
& T_{n s}^{(j)}=\frac{1}{\lambda_{n s}^{* 2}+k_{j}^{2}}\left(\lambda_{n s}^{*} \cos k_{j} \bar{d}+k_{j} \sin k_{i} \bar{d} \operatorname{coth} \lambda_{n s}^{*} \bar{d}\right)
\end{aligned}
$$

$$
\bar{K}_{n j}=\frac{K_{n}^{\prime}\left(k_{j} a\right)}{K_{n}\left(k_{j} a\right)} k_{j}
$$

式(24e)の'は $\partial / \partial\left(k_{j} r\right)$ を表わしている。式(14)，(15a， b)，(16)を式(19)に代入し，両辺に $\cos l_{s} z$ を乗じ， $z$ に関し て区間 $[0, \bar{d}]$ で積分すると次式を得る。

$$
\begin{aligned}
& S_{n s} B_{n 0}+\sum_{j=1}^{\infty} S_{n s}^{(j)} C_{n j}-\frac{\varepsilon_{s} \bar{d}}{2} D_{n s}=0 \quad(s=0,1, \cdots) \cdots(25) \\
& \text { ここに, } \varepsilon_{0}=2, \quad \varepsilon_{s}=1 \quad(s \geq 1) \text { である。 }
\end{aligned}
$$

式(20)，(23)，(25)は，未定係数 $B_{n 0}, C_{n j}(j=1,2, \cdots), D_{n s}$ $(s=0,1, \cdots)$ に関する無限個の連立方程式を構成する。 実際に連立方程式を解く際，jとsに関寸る無限級数は 収束を確認し，ともに10項で打ち切った。未定係数を決 定した後式(15a)に代入し, 式(13)と式(14)を線形 Bernoulli 式に代入すると，海震の作用のもとで運動を拘束された 人工島の下面に生じる動水圧成分 $p_{f}$ が以下のように求 まる。

$$
p_{f}=-\left.\rho_{w}\left(\frac{\partial \phi_{i}}{\partial t}+\frac{\partial \phi_{s}^{(i)}}{\partial t}\right)\right|_{z=\bar{d}}
$$

ここに， $\rho_{w}$ は海水の質量密度である。

$3-2$ 動水圧成分 $p_{m}$ の誘導

人工島の剛体運動と弹性変形により人工島下面に生じ る動水圧成分 $p_{m}$ は, 海震の作用しない静穞な状態にお ける人工島の運動を考之ることにより求妨える。海底 面が剛体的に上下動する場合には人工島は軸対称 $(n=$ 0) 応答となるが, 海底面を水平力向に伝播する地震波に より人工島に励起される応答は, 軸対称応答を含む様々 な円周方向波数 $n$ が励起され，波浪応答と同様に非軸対 称応答の扱いが必要となる。内部領域での放射波の速度 ポテンシャル $\phi_{m}^{(i)}$ は以下の境界值問題を满足する。

$$
\begin{array}{ll}
\nabla^{2} \phi_{m}^{(i)}=0 & : 0 \leq z \leq \bar{d}, r \\
\frac{\partial \phi_{m}^{(i)}}{\partial z}=\frac{\partial \zeta}{\partial t} & : z=\bar{d}, r<a \\
\frac{\partial \phi_{m}^{(i)}}{\partial z}=0 & : z=0, r<a .
\end{array}
$$$$
: 0 \leq z \leq \bar{d}, r<a
$$

式(27b) は人工島下面における人工島と海水の運動の 連続条件を表しており，らは式(1)で与えられる人工島の 全変位である。一方，外部領域での放射波の速度ポテン シャル $\phi_{m}^{(e)}$ は以下の境界値問題を満足する。

$$
\begin{array}{ll}
\nabla^{2} \phi_{m}^{(e)}=0 & : 0 \leq z \leq d, r>a \\
\frac{\partial \phi_{m}^{(e)}}{\partial z}+\frac{1}{g} \frac{\partial^{2} \phi_{m}^{(e)}}{\partial t^{2}}=0 & : z=d, r>a \cdots \\
\frac{\partial \phi_{m}^{(e)}}{\partial z}=0 & : z=0, r>a \cdots \cdots \\
\lim _{r \rightarrow \infty} r^{\frac{1}{2}}\left(\frac{\partial \phi_{m}^{(e)}}{\partial r}+i k \phi_{m}^{(e)}\right)=0 & : r \rightarrow \infty \cdots \cdots \cdots
\end{array}
$$

式 $(28 \mathrm{a} \sim \mathrm{c})$ を満足する内部領域の速度ポテンシャル は次式で与えられる。 


$$
\phi_{m}^{(i)}=\phi_{m h}^{(i)}+\phi_{m p}^{(i)}
$$

ここに, $\phi_{m h}^{(i)}$ は式 (27b)の右辺を 0 とおいたときの同次 解であり左辺の下添字 $s$ を $m$ に置き換えた式(15a)で, $\phi_{m p}^{(i)}$ は $(27 \mathrm{a} \sim \mathrm{c})$ を满足する特解であり次式で与えられ る。

$$
\phi_{m p}^{(i)}=\sum_{n=0}^{\infty} \sum_{m=1}^{\infty} \sum_{s=1}^{\infty} \frac{2 i \sigma}{a \lambda_{n s}} \frac{J_{n}\left(\lambda_{n s}^{*} r\right)}{J_{n+1}^{2}\left(\lambda_{n s}\right)} \frac{\cosh \lambda_{n s}^{*} z}{\sinh \lambda_{n s}^{*} \bar{d}}
$$

$\cdot \int_{0}^{a} \zeta_{n m}(r) J_{n}\left(\lambda_{n s}^{*} r\right) r d r q_{n m}(i \sigma) \cos n \theta \exp (i \sigma t) \cdots(30)$

ここに, $q_{n m}(i \sigma)$ は $q_{n m}(t)=q_{n m}(i \sigma) \exp (i \sigma t)$ で定義さ れる一般化座標の複素振幅である。一方, 式 $(28 \mathrm{a} \sim \mathrm{d})$ を 満足する外部領域の速度ポテンシャル $\phi_{m}^{(e)}$ は, 左辺の下 添字 $s$ を $m$ に置き換之た式(16)で与えられる。

式(29)，(30)，(15a) 㧍よび(16)を式(18a，b)に代入し $\cosh k z$ を両辺に乗じ $z$ に関して区間 $[0, d]$ で積分して得られ る式, 式(29)，(30)，(15a)および(16)を式(18a，b)に代入し $\cos$ $k_{j} z$ を両辺に乗じ $z$ に関して区間 $[0, d]$ で積分して得ら れる式，さらに式(29)，(30)，(15a) 打よび(16)を式(19)に代入し $\cos l_{s} z$ を乗じ $z$ に関して区間 $[0, \bar{d}] て ゙$ 積分した式を以 下にまとめて示す。

$$
\begin{aligned}
& b_{n} B_{n 0}-d_{n} D_{n 0}-\sum_{s=1}^{\infty} \bar{I}_{n s} S_{n s} D_{n s} \\
& =\frac{2 i \sigma}{a^{2}} \sum_{s=1}^{\infty} \sum_{m=1}^{\infty} \bar{J}_{n s} T_{n s} \widetilde{L}_{n m s} q_{n m}(i \sigma) \\
& b_{n}^{(j)} C_{n j}-d_{n}^{(j)} D_{n 0}-\sum_{s=1}^{\infty} \bar{I}_{n s} S_{n s}^{(j)} D_{n s} \\
& =\frac{2 i \sigma}{a^{2}} \sum_{s=1}^{\infty} \sum_{m=1}^{\infty} \bar{J}_{n s} T_{n s}^{(j)} \widetilde{L}_{n m s} q_{n m}(i \sigma) \quad(j=1,2, \cdots) \\
& S_{n s} B_{n 0}+\sum_{j=1}^{\infty} S_{n s}^{(j)} C_{n j}-\frac{\varepsilon_{s} \bar{d}}{2} D_{n s}=0(s=0,1, \cdots) \\
& \text { ここに， } \\
& \tilde{L}_{n m s}=\int_{0}^{a} \zeta_{n m}(r) J_{n}\left(\lambda_{n s}^{*} r\right) r d r
\end{aligned}
$$

である。

式(31a～c) を解き末定係数を決定した後，式(29)に代 入し, さらに以下の Bernoulli 式を用いると人工島の運 動に伴う動水圧成分 $p_{m}$ が求まる。

$$
p_{m}=-\left.\rho_{w} \frac{\partial \phi_{m}^{(i)}}{\partial t}\right|_{z=\bar{d}}-\rho_{w} g \zeta
$$

\section{$3-3$ 䬠留索による変動張力}

人工島をアンカーで繋留すると, 動水圧とともにアン カ一を構成する鉛直繁留索の張力が作用する。円形人工 島の円周にテンションレグをリング状に配置した場合, 円周方向単位長さ当たりの変動張力は次式で与えられ る。

$$
\begin{aligned}
p_{c}(r=a, \theta, t)= & -k_{c}(r=a, \theta)\{\zeta(r=a, \theta, t) \\
& \left.-U_{g}(r=a, \theta, t)\right\} \ldots \ldots \ldots \ldots . . .
\end{aligned}
$$

ここに, $k_{c}(r=a, \theta)$ は媻留索の円周方向単位長さ当た $\eta の$ 剛性であり, $U_{g}(r=a, \theta, t)$ は海底面の上下変位で ある。

円形人工島の底面に一様にテンションレグを配置する 場合, 単位面積当たりの変動張力は次式で与えられる。

$$
p_{d}(r, \theta, t)=-k_{d}(r, \theta)\left\{\zeta(r, \theta, t)-U_{g}(r, \theta, t)\right\} \cdots(35)
$$

ここに, $k_{d}(r, \theta)$ は乿留索の人工島下面単位面積当た りの剛性である。

以下においては，慗留索の剛性が空間座標に独立で一 定と考之，リング状アンカーと分布アンカーの剛性をそ れぞれ $k_{c}(r=a, \theta)=k_{c}, k_{d}(r, \theta)=k_{d}$ とする。

\section{4. 連成振動の定式化}

人工島下面に作用する動水圧とテンションレグの変動 張力を受けて応答する浮遊式円形人工島の運動は以下の Lagrange 方程式に支配される。

$$
\begin{aligned}
& \frac{d}{d t}\left(\frac{\partial T}{\partial \dot{q}_{n m}(t)}\right)-\frac{\partial T}{\partial q_{n m}(t)}+\frac{\partial S}{\partial q_{n m}(t)} \\
& =Q_{n m}^{L}(t)+Q_{n m}^{D}(t)
\end{aligned}
$$

ここに, $Q_{n m}^{L}(t)$ は動水圧と熬留索の変動張力に関連し た $n m$ 次の一般化力, $Q_{n m}^{D}(t)$ は人工島の材料減衰に関連 した $n m$ 次の一般化減衰力である。また， $T$ は人工島の 運動エネルギー, S は人工島のUずみエネルギーであり， それぞれ文献 ${ }^{14)}$ の式(34)，(35)で与えられる。

式(2)を式(36)に代入し，ウェットモード形の直交性を利 用すると，以下のようなモード間連成のない $n m$ 次モ一 ダル運動方程式が導かれる。

$$
\begin{aligned}
& \left(M_{n m}^{P}+M_{n m}^{W}\right) \ddot{q}_{n m}(t)+\left(C_{n m}^{P}+C_{n m}^{W}\right) \dot{q}_{n m}(t) \\
& \quad+\left(K_{n m}^{P}+K_{n m}^{W}+K_{n m}^{T}\right) q_{n m}(t)=Q_{n m}(t) \cdots
\end{aligned}
$$

ここに, $M_{n m}^{P}, C_{n m}^{P}$,および $K_{n m}^{P}$ はそれぞれ人工島の $n m$ 次一般化質量, 一般化減衰, および一般化剛性であり, 文 献 ${ }^{14)}$ の式 $(38 \mathrm{a} \sim \mathrm{c})$ で与之られる。 $M_{n m}^{W}, C_{n m}^{W}$ ，および $K_{n m}^{W}$ はそれぞれ人工島と海水との動的相互作用に伴う $\mathrm{nm}$ 次の一般化付加質量, 一般化付加減衰, および一般化付加 剛性であり，それぞれ文献 ${ }^{14)}$ の式 $(39 \mathrm{a} \sim \mathrm{c})$ で与えられる。 $Q_{n m}(t)$ は $n m$ 次一般化力であり以下のように表せる。

$$
Q_{n m}(t)=Q_{n m}^{F}(t)+Q_{n m}^{T}(t) \quad \cdots \cdots \cdots \cdots \cdots \cdots \cdots \cdots \cdots \cdots(38)
$$

ここに， $Q_{n m}^{F}(t)$ は動水圧 $p_{f}$ に関連した $n m$ 次一般化 力であり， $\theta$ に関して積分した後, 次式で与えられる。

$$
Q_{n m}^{F}(t)=\varepsilon_{n} \pi \int_{0}^{a} p_{f}(r, t) \zeta_{n m}(r) r d r \quad \cdots \cdots \cdots \cdots \cdots \cdots(39)
$$

ここに, $\varepsilon_{0}=2, \varepsilon_{n}=1(n \geq 1)$ である。 $Q_{n m}^{T}(t)$ は媻留 索を伝播する地震波による $\mathrm{nm}$ 次一般化付加入力であ ク， $\theta$ に関して積分した後,慗留方式に対応してそれぞれ 以下のように与えられる。 
・自由浮体の場合

$$
Q_{n m}^{T}(t)=0
$$

・リング状アンカーの場合

$$
Q_{n m}^{T}(t)=\varepsilon_{n} \pi a k_{c} U_{g}(r=a, t) \zeta_{n m}(a)
$$

・分布アンカーの場合

$$
Q_{n m}^{T}(t)=\varepsilon_{n} \pi k_{d} \int_{0}^{a} U_{g}(r, t) \zeta_{n m}(r) r d r
$$

$K_{n m}^{T}$ は媻留索の復元力に伴う一般化付加剛性であり， $\theta$ に関して積分した後, 熬留方式に対応してそれぞれ以 下のように与えられる。

・自由浮体の場合

$$
K_{n m}^{T}=0
$$

・リング状アンカーの場合

$$
K_{n m}^{T}=\varepsilon_{n} \pi a k_{c} \zeta^{2}{ }_{n m}(a)
$$

・分布アンカーの場合

$$
K_{n m}^{T}=\varepsilon_{n} \pi k_{d} \int_{0}^{a} \zeta^{2}{ }_{n m}(r) r d r
$$

一般化剛性 $K_{n m}^{P}$ ，一般化付加剛性 $K_{n m}^{W}$ および $K_{n m}^{T}$, 一 般化質量 $M_{n m}^{P}$, 一般化付加質量 $M_{n m}^{W}$ の間には以下の関 係がある。

$$
K_{n m}^{P}+K_{n m}^{W}+K_{n m}^{T}=\bar{\omega}_{n m}^{2}\left(M_{n m}^{P}+M_{n m}^{W}\right)
$$

ここに， $\bar{\omega}_{n m}$ は人工島のウェットモードの $n m$ 次固有 円振動数である。式(42)を式(37)に代入し，耐辺を $\left(M_{n m}^{P}\right.$ $\left.+M_{n m}^{W}\right)$ で除すと調和入力に対する $n m$ 次モ一ダル運動 方程式は最終的に以下のようになる。

$$
\begin{gathered}
\ddot{q}_{n m}(t)+2\left(\bar{\xi}_{n m}+\bar{\xi}_{n m}^{*}\right) \bar{\omega}_{n m} \dot{q}_{n m}(t)+\bar{\omega}_{n m}^{2} q_{n m}(t) \\
\quad=\frac{Q_{n m}(t)}{M_{n m}^{P}+M_{n m}^{W}} \ldots \ldots \ldots \ldots \ldots \ldots \ldots \ldots \ldots \ldots \ldots \ldots \ldots \ldots \ldots \ldots \ldots \ldots \ldots \ldots \ldots \ldots \ldots
\end{gathered}
$$

ここに， $\bar{\xi}_{n m}$ は海上における人工島の $n m$ 次材料減衰 比， $\bar{\xi}_{n m}^{*}$ は人工島の運動による表面波発生に伴う $n m$ 次 造波減衰比であり，それぞれ文献 ${ }^{14)}$ の式(44a，b)で与え られる。

\section{5 . 定常ランダム応答}

海底面に扮ける上下動加速度の定常部の周波数特性 は，次式の修正金井・田治見パワースペクトル密度関数 で与えられるものと仮定する。

$$
\begin{aligned}
& S_{\ddot{U}_{g} \dot{v}_{g}}(\sigma)= S_{0}\left[\frac{1+4 \xi_{g}^{2}\left(\sigma / \omega_{g}\right)^{2}}{\left\{1-\left(\sigma / \omega_{g}\right)^{2}\right\}^{2}+4 \xi_{g}^{2}\left(\sigma / \omega_{g}\right)^{2}}\right] \\
& \cdot\left[\frac{\left(\sigma / \omega_{k}\right)^{4}}{\left\{1-\left(\sigma / \omega_{k}\right)^{2}\right\}^{2}+4 \xi_{k}^{2}\left(\sigma / \omega_{k}\right)^{2}}\right] \\
&(-\infty<\sigma<+\infty) \cdots \cdots \cdots(44)
\end{aligned}
$$

ここに, 右辺の 1 番目の大カッコは金井・田治見18)の口 ウパスフィルター, 2 番目の大カッコはClough • Penzien ${ }^{199}$ のハイパスフィルターである。また， $S_{0}$ はスぺ クトル強度, $\xi_{g}$ と $\omega_{g}$ は口ウパスフィルターのパラメー タであり，それぞれ地盤の代表滅衰比と代表円振動数に
対応している。 $\xi_{k}$ と $\omega_{k}$ はハイパスフィルターのパラ メー夕である。式(44)から，海底面における上下動変位の パワースペクトル密度関数 $S_{U_{o} U_{o}}(\sigma)$ は以下のように定ま る。

$$
S_{U_{o} U_{\theta}}(\sigma)=S_{U_{\theta} \ddot{U}_{\theta}}(\sigma) / \sigma^{4}
$$

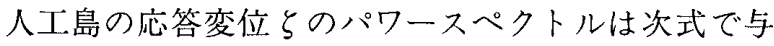
えられる。

$$
\begin{aligned}
& S_{\zeta \xi}(r, \theta, \sigma) \\
& =\sum_{n=0}^{\infty} \sum_{m=1}^{\infty} \zeta_{n m}^{2}(r) \cos ^{2} n \theta\left|H_{n m}(\sigma)\right|^{2} S_{Q_{n m} Q_{n m}}(\sigma) \\
& \text { ここに, } \\
& \begin{aligned}
\left|H_{n m}(\sigma)\right|^{2}= & 1 /\left(M_{n m}^{P}+M_{n m}^{W}\right)^{2}\left[\left(\bar{\omega}_{n m}^{2}-\sigma^{2}\right)^{2}\right. \\
& \left.+4\left(\bar{\xi}_{n m}+\bar{\xi}_{n m}^{*}\right)^{2} \bar{\omega}_{n m}^{2} \sigma^{2}\right] \ldots . . .
\end{aligned}
\end{aligned}
$$$$
=\sum_{n=0}^{\infty} \sum_{m=1}^{\infty} \zeta_{n m}^{2}(r) \cos ^{2} n \theta\left|H_{n m}(\sigma)\right|^{2} S_{Q_{n m} Q_{n m}}(\sigma) \cdots \cdots(46)
$$

また, $S_{Q_{n m} Q_{n m}}(\sigma)$ は一般化力 $Q_{n m}(t)$ のパワースペクト ルで式(44)の $S_{\ddot{U}_{o} \ddot{U}_{\theta}}(\sigma)$ と式(45)の $S_{U_{o} U_{0}}(\sigma)$ の関数である。式 (46)を全周波数領域で樍分することにより, 変位応答 $\zeta の$ 分散（二乗平均值）が求まる。

$$
\begin{aligned}
\bar{\zeta}^{2}(r, \theta)=\operatorname{Var}[\zeta] & =\int_{0}^{\infty} S_{\zeta \zeta}(r, \theta, \sigma) d \sigma \\
& =\sum_{n=0}^{\infty} \sum_{m=1}^{\infty} \zeta_{n m}^{2}(r) \cos ^{2} n \theta \bar{q}_{n m}^{2}
\end{aligned}
$$

ここに， $\bar{q}_{n m}^{2}$ は $n m$ 次一般化座標の分散 (二乗平均值) であり，次式で与えられる20。

$$
\begin{aligned}
\bar{q}_{n m}^{2} & =\int_{0}^{\infty}\left|H_{n m}(\sigma)\right|^{2} S_{Q_{n m} Q_{n m}}(\sigma) d \sigma \\
& \fallingdotseq \frac{\pi}{4\left(M_{n m}^{P}+M_{n m}^{W}\right)^{2}\left(\bar{\xi}_{n m}+\bar{\xi}_{n m}^{*}\right) \bar{\omega}_{n m}^{3}} S_{Q_{n m} Q_{n m}}\left(\bar{\omega}_{n m}\right)
\end{aligned}
$$

同様に人工島に生じる加速度や応力の応答の分散も求 めることができる。

\section{6. 数值結果と検討}

数値例題におけるモデルパラメータを以下のように定 める。人工島は内部に隔壁を有する大型コンクリート製 バージを想定し, 半径 $=1000 \mathrm{~m}$, 厚さ $=50 \mathrm{~m}$, ヤング係 数 $=2.0 \times 10^{10} \mathrm{~N} / \mathrm{m}^{2}$, ポアソン 比 $=0.15$, 質量密度 $=$ $0.4 \times 10^{3} \mathrm{~kg} / \mathrm{m}^{3}$, 陸上でのモード減衰比は各モードとも 0.05 とする。槃留時には自由浮体状態から $5 \mathrm{~m}$ 引き込む ものとする。海水に関しては, 質量密度 $=1.05 \times 10^{3} \mathrm{~kg} /$ $\mathrm{m}^{3}$, 設置水深 $=200 \mathrm{~m}$ とする。アンカーに関しては, リン グ状アンカーの剛性 $k_{c}=5.0 \times 10^{6} \mathrm{~N} / \mathrm{m}^{2}$, 分布アンカー の剛性 $k_{d}=5.0 \times 10^{5} \mathrm{~N} / \mathrm{m}^{3}$ とする。海底面を水平方向に 伝播する地震波の見かけ速度として $C_{a}=1 \times 10^{3}, 3 \times$ $10^{3}, 5 \times 10^{3} \mathrm{~m} / \mathrm{sec}$ を考之，海底面が剛体的に上下動する 場合 $\left(C_{a}=\infty\right)$ と比較する。海底面での上下動の加速度 パワースペクトル密度関数のハイパスフィルタとローパ 
(a) Without

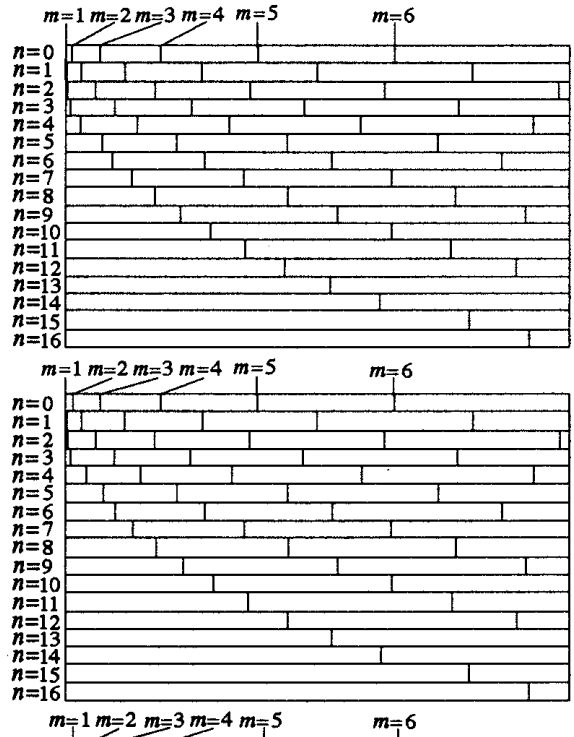

(b) Ring

(c) Distributed
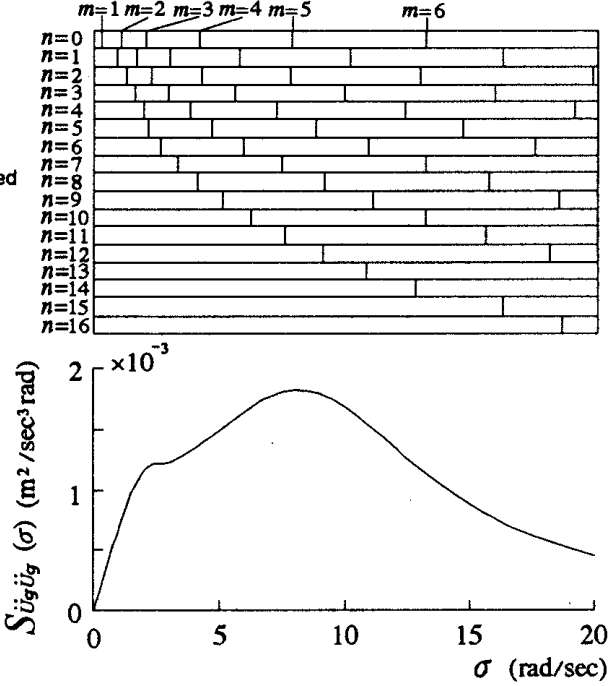

Fig. 6a Wet-mode natural frequencies and power spectral density function of vertical ground acceleration

(a) Without

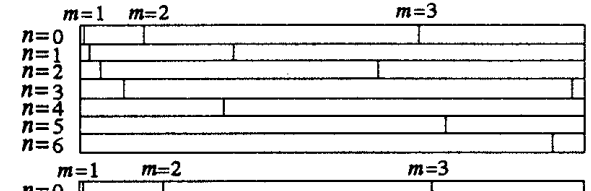

(b) Ring

(c) Distributed
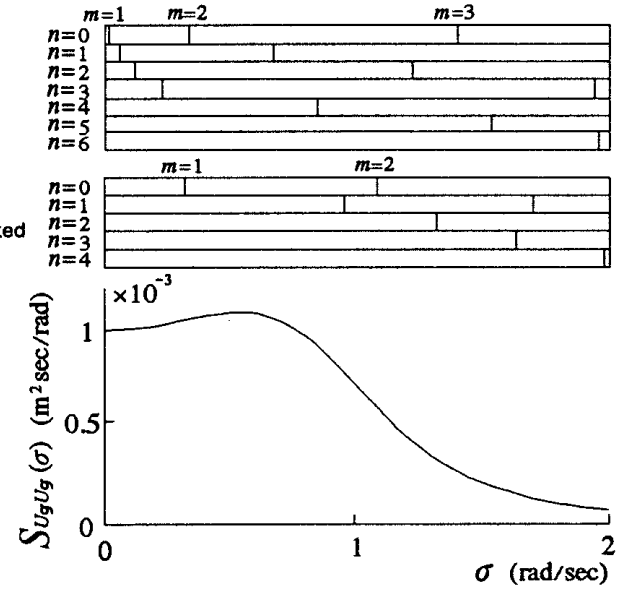

Fig. 6b Wet-mode natural frequencies and power spectral density function of vertical ground displacement
スフィルタのパラメータの值は $\omega_{g}=10 \mathrm{rad} / \mathrm{sec}, \xi_{g}=$ $0.6, \omega_{k}=1 \mathrm{rad} / \mathrm{sec}, \xi_{k}=0.6$, スペクトル強度は $S_{0}=1.0$ $\times 10^{-3} \mathrm{~m}^{2} / \mathrm{sec}^{3}$ とした。

Fig. 6a，bに海底地盤の上下動加速度および上下動変 位のパワースペクトル密度関数と各槃留方式における人 工島のウェットモードの固有振動数との関係を示す。い ずれの槃留状態においても，多くの弾性モ一ドが上下動 の加速度スペクトルの主要領域に入っている。しかし， 変位スペクトルの主要領域に入るのは低次モードのみで ある。リング状アンカーの固有振動数の位置は自由浮体 状態と似ているが，分布アンカーでは各モードとも大幅 に高振動数側に移動している。スペクトルと固有振動数 の関係に基づき, 解析では円周方向波数 $n$ が 0 から 16 ま で, 半径方向モード次数 $m$ が 1 から 6 までのモードのう ち $20 \mathrm{rad} / \mathrm{sec}$ 以下の55モードを考慮した。

Fig. 7 に変位応答の標準偏差の $\theta=0$ における半径方 向分布を示す。 $r=0$ は人工島の中心点に对応してる。い ずれの慗留状態においても低次モードのみが励起されて

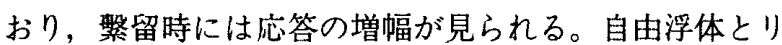

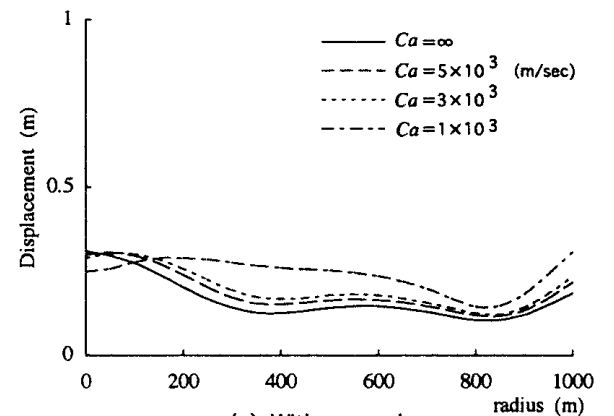

(a) Without anchor

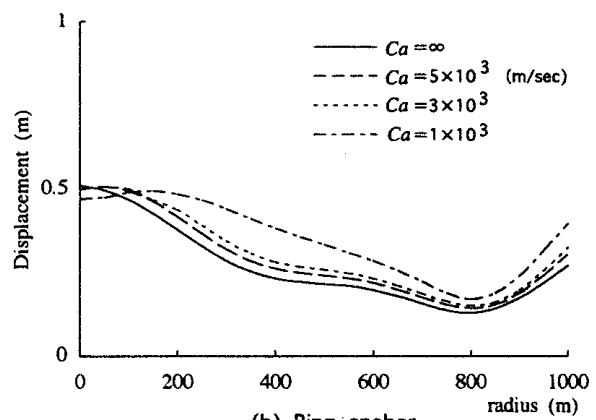

(b) Ring anchor

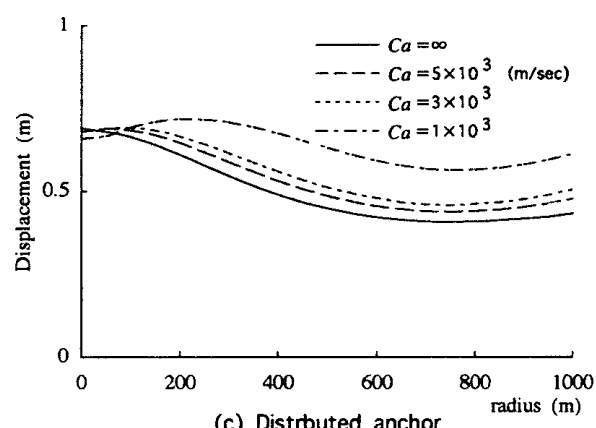

Fig. 7 Displacement responses of the floating island 
ング状アンカーでは人工島端部での変形が顕著であり, 分布アンカーでは変形が抑之られ剛体運動が卓越してい る。いずれの繫留状態においても，地震動の位相差がな い場合 $\left(C_{a}=\infty\right)$ に比べて位相差を有する場合の応答值 が大きく, 水平方向進行波の見かけ速度 $C_{a}$ が小さいほ ど応答值は大きくなっている。

Fig. 8 に上下加速度応答の標準偏差の $\theta=0$ における 半径方向分布を示す。いずれの繫留状態においても，高 次モードの励起が顕著であり, 応答の半径方向分布の形 状は複雑になっている。地震動の位相差がない場合は人 工島中央部における応答の増幅が大きく, 位相差を有す る場合はこの傾向が弱まる。人工島中央部の応答は，位 相差のないときに最も大きくなり，位相差のあるときは 見かけ速度 $C_{a}$ が大きいほど応答が大きい。しかし，中央 部以外の領域では位相差のないときに比べて位相差を有 するときの方が応答は大きい。また見かけ速度 $C_{a}$ が小 さいほど応答值は全体的に小さくなる傾向がみられる。

Fig. 9 に半径方向曲げモーメントの標準偏差の $\theta=0$
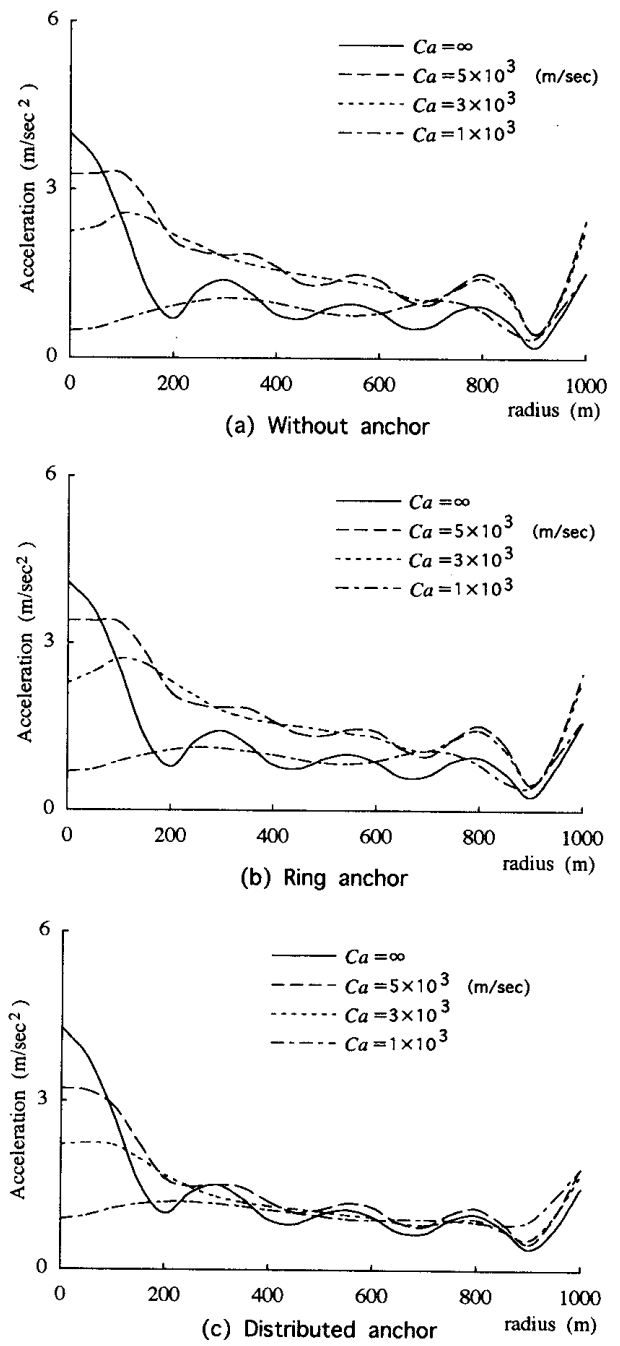

Fig. 8 Acceleration responses of the floating island
における半径方向分布を示す。自由浮体と分布アンカー に比べてリング状アンカーの場合に応答が大きい。いず れの繫留状態においても，人工島中央部を除き地震動の 位相差がないときの応答は最も小さくなり，位相差があ るときは応答值が増加している。

\section{7.むすび}

線形ポテンシャル理論に基づき, 海底面を地震波が水 平方向に伝播する際に生じる海震現象により大規模浮遊 式人工島に作用する動水圧を解析的に求め, ウェット モード合成法と定常ランダム振動理論により人工島の応 答挙動を予測する方法を示した。本研究の範囲内で，入 力地震波の位相差を考慮した人工島の海震応答の特徵は 以下のように要約される。

1）入力地震波の位相差がある場合は，ない場合に比べ て人工島の変位応答は大きくなる。水平方向進行波の 見かけ速度 $C_{a}$ が小さいほど芯答は増加する傾向があ る。
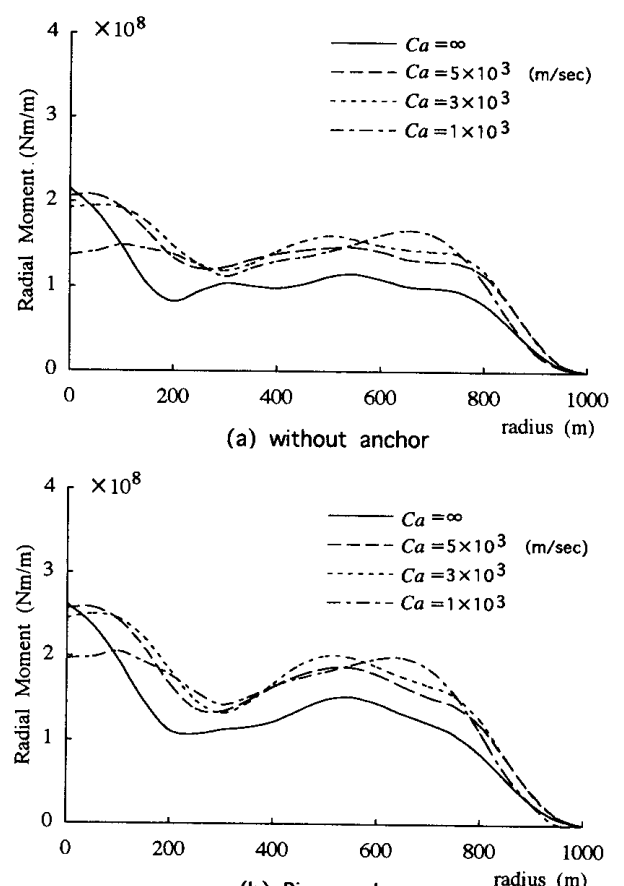

(b) Ring anchor

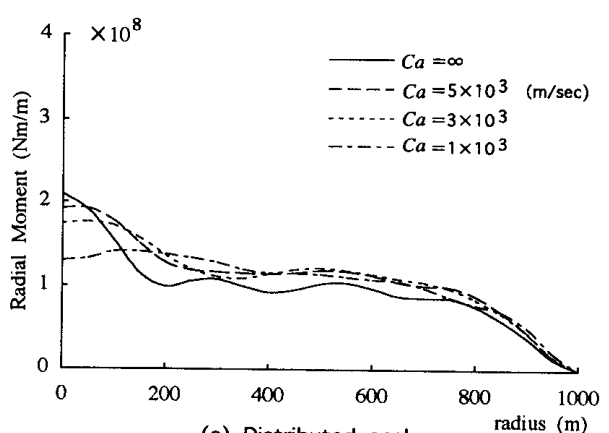

(c) Distributed anchor

Fig. 9 Radial bending moment responses in the floating island 
2 ）高次モードの励起により加速度応答の分布形は変位 応答よりも複雑である。人工島中央部の応答は入力地 震波の位相差がないときに最も大きく，位相差がある ときは見かけ速度 $C_{a}$ が大きいほど応答も大きい。し かし, 中央部以外の領域では位相差のないときの応答 が最も小さくなる。位相差のあるときは $C_{a}$ が小さく なるにつれ全体の応答が低下寸る傾向がある。

3 ）曲げモーメントの応答は局部的に拘束したリング状 アンカーの場合に大きくなる。人工島中央部では入力 地震波の位相差がないときの応答が大きくなるが，そ れ以外の領域では位相差のある方が応答は大きい。

\section{参考文献}

1) Hove, K., Selnes, P., Bungum, H.: Seaquakes: A Potential Threat to Offshore Structure, Proc. of the 3rd Symp. on the Behavior of Offshore Structure, Vol. 2, pp. $561 \sim 571,1982$

2) Ambraseys, N.: A Damaging Seaquake, Earthquake Eng. and Structural Dynamics, Vol. 13, pp.421 424, 1985

3) Baba, E.: A Study on the Effect of Seaquakes on a Floating Body, 日本造船学会論文集, 第162号, pp.90 98, 1988

4）川西利昌, 池田信昭, 加藤涉: 垂直地震動に上る緊張媻留 浮体の応答, 日本造船学会論文集, 第161号, pp.307 315, 1987

5）川西利昌, 加藤貴司, 小林浩：オフセット状態に拈计るテ ンションレグプラットホームの地震応答解析, 日本建築学 会講造系論文報告集，第427号，pp.117～126，1991

6) Liou, G.S., Penzien, J., Yeung, R.W. : Response of Tention-leg Platforms to Vertical Seismic Excitations, Earthquake Eng. and Structural Dynamics, Vol. 16, pp. $147 \sim 182,1988$

7) 濱本卓司, 田中慗壽雄：海震を受ける浮遊式海洋人工島の 応答挙動（浮逰弹性円板の流体～構造物相互作用解析その 3 ), 日本建築学会構造系論文報告集, 第 448 号, pp. 173 185, 1993

8) Wolf, J.P., Obernhuber, P.: Effect of Horizontally Traveling Waves in Soil-Structure Interaction, Nuclear Eng. and Design, Vol. 57, pp.221 244, 1980

9) Wolf, J.P., Obernhuber, P.: Free-Field Response from Inclined SV- and P.Waves and Rayleigh Waves, Earthquake Eng. and Structural Dynamics, Vol. 10, pp.847 $\sim 869,1982$

10) Wolf, J.P., Bucher, K.M. : Nonlinear Traveling Wave Effects on Cooling Tower, J. of Structural Div., ASCE, Vol. 108, pp.1424 1439, 1982

11) Wolf, J.P., Obernhuber, P., Weber, B.: Response of a Nuclear Power Plant on a Seismic Bearing to Horizontally Propagating Waves, Earthquake Eng. and Structural Dynamics, Vol. 11, pp.483 499, 1983
12) Somaini, D.R. : Seismic Behavior of Girder Bridges for Horizontally Propagating Waves, Earthquake Eng. and Structural Dynamics, Vol. 15, pp.777 793, 1987

13) O'Rourke, M.J., Hmadi, K.E.: Analysis of Continuous Buried Pipelines for Seismic Wave Effects, Earthquake Eng. and Structural Dynamics, Vol. 16, pp.917 929, 1988

14）濱本卓司，田中彌壽雄：風波を受ける浮遊式海洋人工島の 応答誉動（浮遊弾性円板の流体一構造物相互作用解析その 2), 日本建築学会構造系諭文報告集，第442号，pp. $157 \sim 167,1992$

15）濱本卓司, 田中㣆壽雄：浮遊式海洋人工島の連成自由振動 特性（浮遊弾性冈板の流体～構造物相互作用解析その 1), 日本建築学会構造采論文報告集, 第438号, pp.165 177, 1992

16) Hamamoto, T., Asami, T.: Fluid-Coupled Free Vibration of Floating Elastic Circular Plates with Elastically Supported Edge, Theoretical and Applied Mechanics, Vol. 43, pp.171 179, 1994

17) MacCamy, R.C., Fuchs, R.A.: Wave Forces on a Pile : A Diffraction Theory, Tech. Memo 69, U.S. Army, Corps of Engineers Beach Erosion Board, 1954

18) Tajimi, H. : Statistical Method of Determining the Maximum Response of Building Structure During an Earthquake, Proc. of the 2nd World Conf. on Earthquake Eng., Tokyo, Vol. 2, pp.781 798, 1960

19) Clough, R.W., Penzien, J.: Dynamics of Structures, Mc-Graw-Hill, 1975

20) Hurty, W.C., Rubinstein, M.F. : Dynamics of Structures, Prentice-Hall, 1964

21）濱本卓司, 加村久哉, 田中雵壽雄：海震に对寸る大規模浮 遊式人工島の動的解析, 第 8 回日本地震工学シンポジウム 論文集, Vol. 2，pp.1323 1328，1990

22) Hamamoto, T., Takahashi, H., Tanaka, Y.: Stochastic Response of Anchored Flexible Floating Islands Subjected to Wind-Waves and Seaquakes, Proc. of the 1st Int. Offshore and Polar Eng. Conf., Edinburgh, Vol. 3, pp.391 $\sim 398,1991$

23）濱本卓司, 高橋浩史, 田中彌壽雄：浮遊式海洋人工島の波 浪および海震に対する流体連成挙動の統一的扱いに関し て, 構造工学論文集, Vol. 37B, pp.87 99, 1991

24）濱本卓司, 佐々木仁, 高橋浩史, 田中诵漀雄：浮遊式海洋 人工島の流体連成挙動におけるアンカーの影響に関して, 構造工学論文集, Vol. 38B, pp.81 92, 1992

25) Hamamoto, T.: Dynamic Response of Flexible Circular Floating Islands Subjected to Stochastic Waves and Seaquakes, Proc. of Int. Conf. on Hydroelasticity in Marine Technology, Trondheim, pp.433 445, 1994

26）濱本卓司，三角猛二郎，田中诵壽雄：海底面での上下地動 の位相差を考虑した浮遊式海洋人工島の海震応答, 第 9 回 日本地震工学シンポジウム論文集, Vol. 2, pp.1285 1290, 1994

（1995年10月31日原稿受理，1996年 2 月20日採用決定） 